\title{
Islam and Homosexuality
}

\author{
Rusi Jaspal \\ De Montfort University, Leicester, UK
}

While homosexuality has gained greater social acceptance in many Western societies, it remains highly stigmatized and, in most cases, forbidden in mainstream Islam. Theologically-based homophobia has given rise to negative social representations of homosexuality in Muslim communities around the world. Lesbian, gay and bisexual (LGB) Muslims themselves are acutely aware of the stigma of homosexuality, and the prejudice and, in some cases, harsh punishment that they may face if they disclose their sexual identity. This can in turn induce threats to identity and compromise psychological wellbeing. This entry pieces together emerging empirical evidence on the interface of homosexuality and Islam, focusing upon the theological (meso), social (macro) and psychological (micro) levels of analysis.

\section{Islamic Theological Constructions of Homosexuality}

Like most religious traditions, Islamic ideology appends hegemonic status to heterosexuality, and is deeply opposed to homosexuality. This stance is ingrained in the major ideological channels of communication, such as Islamic holy scripture (the Koran), Islamic law (Shari'ah), and the verbal teachings of the Prophet Mohammed (Ahadith), all of which appear to outlaw homosexuality (Bouhdiba, 1998). Theological opposition to homosexuality is based on what is regarded by most Islamic scholars as the Koran's explicit prohibition of same-sex sexuality. The story of Lot in the Koran has been widely cited as evidence of God's condemnation of homosexuality. The Koran makes seven explicit references to the people of Lot, whose destruction by God is often attributed to their engagement in homosexual practices, as exemplified in the following passage:

What! Of all creatures do ye come unto the males,

And leave the wives your Lord created for you?

Nay but ye are forward folk...

And we rained on them a rain. And dreadful is the rain of those who have been warned.

(Pickthall translation, 26.165-73)

Although there has been some variation in the interpretation of the Story of Lot (Kugle, 2010), there is one passage in the Koran that more clearly demonstrates the illegality of homosexuality:

And as for the two of you who are guilty thereof [of homosexuality], punish them both. And if they repent and improve, then let them be. Lo! Allah is ever relenting, Merciful. (4.16)

In Islam, the Koran legislates all aspects of social life but interpretations of the text have varied in accordance with time and space, and some interpretations have been favored over others by particular denominations of Islam. Yet, in their reading of the story of Lot, most Muslim scholars advocate that homosexuality is an aberration and violation of nature, as well as a revolt against God.

Although there has been some discussion of the authenticity and accuracy of the Hadith (sayings attributed to the Prophet Mohammed), they are frequently invoked by Islamic scholars in order to substantiate the dominant Islamic position on homosexuality:

The Prophet said: If you find anyone doing as Lot's people did, kill the one who does it, and the one to whom it is done. (Abu Dawud 4462, Book 39, Hadith 4447)

Like other Ahadith, this one constructs homosexual acts as both immoral and illegal, and homosexuals as deserving of capital punishment. They construct both the active and passive 
individuals as equally culpable, although in societal thinking the passive role appears to be more stigmatized (see below). Although the Quran does not appear to make overt reference to lesbian sexuality, there are Ahadith that suggest that lesbian sexual activity is sinful in that it is comparable to "zina" (adultery) and, thus, punishable by death. Like most religious traditions, Islam emphasizes the complementarity and unity of the two sexes, with distinguishable gender roles associated with each. Given that homosexuality can undermine this patriarchal social structure, Islamic ideology strictly opposes it (Duran 1993).

Most Islamic countries prohibit homosexuality and in many of them it is punishable by death. Only a handful of Islamic or Muslim-majority countries (e.g. Jordan) have legalized homosexuality, but even in these societies there is little legal support for LGBT individuals and extra-judicial punishments may be meted out. The Islamic Republic of Iran, which is ruled by sharī' $a$ law, has a particularly harsh legal stance on homosexuality. Iranian law dictates that two unrelated men lying under the same bed cover will be punished with 60 lashes; that homosexual relations without anal penetration carries a penalty of 100 lashes; and that anal intercourse will be punished with death by hanging. Between 1979 and 1990 some 107 executions for homosexuality were recorded. According to sharí' $a$, individuals can be convicted of homosexuality only if they confess four times or if four "righteous" Muslim men testify that they have witnessed a homosexual act taking place. In Islamic societies, both judicial and extra-judicial measures taken against homosexuality communicate a clear message to society that homosexuality is wrong, immoral, illegal and, thus, punishable.

There is now an emerging "reverse discourse" concerning the Islamic position on homosexuality, with some scholars arguing that there is indeed scope for the theological accommodation of homosexuality. For instance, Wafer (1997) indicates that the mildness of the Koranic passages alluding to homosexuality vis-à-vis other religious infractions perhaps indicates that "the Prophet took a lenient attitude toward sex between males" (p.89). Some have contested the dominant interpretation of the Story of Lot, and argued that its destruction reflected God's condemnation of the people's promiscuity, violence, inhospitality etc., rather than homosexuality per se (Kugle, 2010; Jamal, 2001). Accordingly, Duran (1993, p. 181) has indicated that gay Muslims need to seek out a "theological accommodation" of their sexuality, based on a "new shar $\bar{l}$ ' $a$ " that emphasizes the principles of freedom and justice that are central to Islam. However, it is noteworthy that such theological accommodation is still in its infancy, given that "there are at present limited efforts in Islamic theology which offer non-heterosexual Muslims resources to construct a reverse discourse" (Yip, 2005, p.50)

\section{Homosexuality in Muslim Societies}

In view of such intolerance at the theological, legal and institutional levels, it is unsurprising that social representations of homosexuality remain negative within Muslim communities. There is little research into attitudes towards homosexuality among Muslims, largely because of the difficulties associated with conducting empirical research into such a taboo topic. Moreover, as argued by Murray (1997), there is a culture of collective denial of homosexuality in Islamic societies. However, in a large-scale international study of global attitudes towards homosexuality conducted by the Pew Research Centre, it was found that less than 5\% of the people surveyed in Egypt, Indonesia, Jordan, Pakistan, the Palestinian Territories, and Tunisia believed that society should accept homosexuality, compared to $80 \%$ of the Canadians and $76 \%$ of the Britons surveyed. The only Muslim-majority countries that expressed greater support were Malaysia (9\%), Turkey $(9 \%)$ and Lebanon (18\%), in which Islam arguably plays a less central role in social and political life. The study revealed little difference in levels of homophobia among younger and older generations in Muslim-majority societies. This suggests that homophobic social representations are pervasive and coercive across various demographic groups. Moreover, even in diasporic Muslim communities in the West there appears to be higher than average levels of homophobia. 
For instance, in a 2009 Gallup poll in the UK it was found that none of the 500 Muslim respondents regarded homosexuality as "morally acceptable". Similarly, a 2007 survey found that $61 \%$ of the Muslims surveyed believed that "homosexuality is wrong and should be illegal" with the view most consensually held by respondents aged between 16-24 (Mirza et al., 2007). Despite socialization in the UK, which can be regarded as a relatively LGBT-affirmative society, young British Muslims still appear to hold negative social representations of homosexuality, which can be attributed to theological sources.

Although there seems to be almost consensual opposition to homosexuality at a social level, there are some exceptions. In Islamic societies with very strict gender segregation limiting contact between young men and women, same-sex activity often occurs and may even be silently tolerated provided that it is not discussed openly and key social, cultural and religious norms (e.g. heterosexual marriage) are not violated (Murray, 1997). Homosexual activity may be cynically mapped onto heterosexual activity whereby the penetrating ("active") individual retains his sense of masculinity and virility, while the penetrated ("passive") individual is viewed as the feminine. There is a social representation that the active individual, while guilty of immorality, is not actually homosexual at all and, thus, is less reprehensible than the passive individual. There is limited but growing work on the sociology of lesbian sexuality, which suggests that Muslim lesbians may remain invisible and that there is a lack of acknowledgement of their identities (Ahmed-Ghosh, 2012). In Iran, for instance, where lesbian sexual activity may be acknowledged, it too is often regarded in heteronormative terms, as a question to be resolved through gender reassignment (Bucar \& Shirazi, 2012). Homosexuality tends to be conceptualised in primarily sexual terms, that is, as a sexual act/ behavior, rather than as an emotional, sentimental or psychological identity in the Western sense of coming out as exclusively gay (Duran, 1993).

Indeed, when looking at the labels that tend to be used to denote homosexuality in Islamic societies, it is evident that there is a focus upon the sexual activity, rather than identity. Many colloquial terms append negative valence to homosexuality. Key labels used in Muslim societies include the Arabic term lüt (which is an allusion to the people of Lot), the Farsi term kuni (the agentive noun derived from the noun kun, meaning "ass") and the Urdu/Punjabi term gandu (the agentive noun derived from the noun gand, meaning "anus"). Clearly, such pejorative labels anchor homosexuality to immorality and un-Islamic activity (in the case of $l \bar{u} t \bar{t}$ ), and to the sexual dimension of homosexuality, emphasizing carnal desire, rather than emotion or identity.

\section{Psychological Interactions with Homosexuality}

Many LGB Muslims find that they must construct their sexual identities against the backdrop of negative theological, legal and social representations of homosexuality. A number of empirical studies have examined the interface of religion and sexuality among LGB Muslims of diverse ethnic backgrounds. These studies converge in demonstrating the immense social and psychological obstacles that LGB Muslims may face in constructing a positive self-concept that includes their sexual identity. Recently, there has been an empirical focus on the identities and experiences of British Muslim gay men, which demonstrates the multiple ways in which individuals make use of their social contexts and group memberships to cope with threats to identity. In this section of the entry, some of this research is summarized as a means of outlining the psychological implications of being gay and Muslim.

Most research in this area has focused upon the effects that one's sexual and religious identities can have for one's self-concept, using Identity Process Theory (Breakwell, 1986). The theory argues that individuals seek to construct an identity that is characterized by (i) a sense of continuity over time, (ii) distinctiveness from others, (iii) a sense of self-efficacy, (iv) self-esteem, and (v) coherence between identities. It is argued that, when any of these important identity principles are in any way jeopardized, identity is threatened. Identity threat is aversive for psychological wellbeing and, thus, individuals attempt to cope with it. 
Coping strategies can include inter alia denial, isolation, self-acceptance, and engagement in social support groups.

Extensive in-depth interview research has generally shown that Muslim gay men are susceptible to identity threat on various levels. First, gay Muslims often perceive incompatibilities between their religious and sexual identities, which can threaten coherence. Theological, legal and social representations construct homosexuality as being fundamentally opposed to Islamic norms and values, which can induce a perception that one is "going against God" (Jaspal \& Cinnirella, 2010, p.861). Second, engagement in same-sex behavior can lead gay Muslims to question both their heterosexuality and their Muslim identity, both of which are desired selves, that is, things that they wish to be (Jaspal \& Cinnirella, 2014). This can induce discontinuity in the psychological thread connecting past, present and future, thereby threatening continuity. Third, the representation of homosexuality as an abomination and its theological/ legal and social anchoring to sin and evil can lead to a negative self-conception - individuals see their behavior and identity as being fundamentally wrong, potentially resulting in threats to self-esteem. Fourth, gay Muslims often report that they wish to "become straight", which many regard as the "right path" for a Muslim to take. The inability to change one's sexual orientation and their failure to suppress same-sex desire can translate into a threatened sense of self-efficacy - that is, a perception that one has no control over one's identity and future (Jaspal \& Cinnirella, 2010). There has been very few studies of how Muslim lesbians experience their sexuality and religion - Siraj's (2012) study echoes some of the issues described in relation to Muslim gay men, but adds that Muslim lesbians may re-define the nature of their relationship with Islam and come to manifest a more spiritual, rather than institutional, attachment to their religion.

Given the multiplicity of threats that gay Muslims seem to face, it is appropriate to talk of hyper-threats to identity. Threats to the identity principles ensue primarily from the perception that both same-sex acts and a gay identity are fundamentally inconsistent with Islam. Due to the priority that the vast majority of Muslims append to their religious identity (often displacing other identities), Islam functions as a heuristic lens for regarding and interpreting the social world and, indeed, other aspects of the self, such as sexuality. Indeed, some Muslim lesbians may feel that they are undermining the values and tenets of Islam because of their sexual identity (Siraj, 2012). Muslim identity remains at the social and psychological forefront.

Identity threat is said to have negative social, psychological and emotional outcomes (Breakwell, 1986; Jaspal, 2012). The available empirical evidence suggests that gay Muslims experience difficulties in coping adequately and enduringly. In a study of managing homosexuality and Islam, Jaspal and Cinnirella (2010) found a tendency for gay Muslims to engage in external attribution - amid the threats to identity, they attributed their sexual orientation to an external source. Those who accepted and sought to embrace their sexuality as an identity viewed it as "God's creation" and argued that a perfect God would not have created an imperfect identity, although this perspective met with considerable opposition from others. Conversely, those who sought to distance themselves from their sexual orientation attributed it to Satan's attempts to divert Muslims from good towards evil and conceptualized it as "a test". They hoped to be able to change their sexual orientation in the future and yearned for the forgiveness of Allah. Some individuals conceptualized their homosexuality as a mutable behavior, rather than as an identity, because it enabled them to believe that they would eventually change. After all, behaviors are generally viewed as being more mutable than identities. Denial is a common coping strategy, also with limited efficacy in the long-term. Gay Muslims may deny that they are gay, opting for self-definition as straight or bisexual, despite acknowledging that they feel little or no sexual attraction to women. Self-definition in these terms can allow individuals to continue to engage in same-sex relations without the psychological burden of acknowledging this as an identity. Moreover, when overwhelmed by religious and cultural norms, such as the expectation of an arranged heterosexual marriage, gay Muslims may disengage with reality and engage in deflection strategies, such as denial of their sexuality or of the long-term implications of a heterosexual 
marriage (Jaspal, 2014a). While these strategies buffer identity from threat in the short-term, none of them are conducive to a positive self-concept in the long-term.

Social psychology has long acknowledged that social support is the most promising means of coping with social and psychological distress, including identity threat, partly because it can lead to forms of self-acceptance. However, there are few social support mechanisms in place for gay Muslims - many feel unable to disclose their sexuality to significant others due to fear of ostracization, and there are few LGBT-affirmative Islamic organizations that can provide the social and psychological conditions for identity coherence (Jaspal, in press). However, there have been some moves towards the theological accommodation of homosexuality. The US-based AlFatiha Foundation was established in 1997 in order to advocate rights for LGBTQ Muslims and to foster the acceptance of homosexuality in Islam. Al-Fatiha was disbanded in 2011, but in 2013 the Muslim Alliance for Sexual and Gender Diversity took on the mission to "support, empower and connect LGBTQ Muslims" and to "increase the acceptance of gender and sexual diversity within Muslim communities". In 1999, Al-Fatiha UK (later renamed Imaan) became the first UK-based support group organization for LGBT Muslims and remains active in promoting the reconciliation of homosexuality and Islam. As Breakwell (1986, p. 130) notes, "[i]ndividuals experiencing threat can come together with others who share their predicament or who are sympathetic to their cause to create a new group." Clearly, consciousness-raising and self-help groups focused on homosexuality and Islam can create a wealth of social and psychological opportunities for gay Muslims who experience identity threat.

\section{Homosexuality and Islam: Ways Forward}

This entry has shown how theological, legal and social representations in mainstream Islam construct homosexuality as wrong, immoral and sinful. Although there has been some debate concerning the mainstream Islamic stance on homosexuality, the theological accommodation of homosexuality is still in its infancy and has yet to make a discernible impact on mainstream Islam and on dominant beliefs within Muslim communities. While these representations provide the impetus for hostility, homophobia and discrimination from sections of the Muslim community, they also have powerful social and psychological implications for gay Muslims who struggle to construct a positive sexual identity. Such representations are often conducive to hyper-threats to identity, which can have detriment effects for social and psychological wellbeing. Islam is an important and often "core" identity among Muslims, both heterosexual and LGB alike, and, thus, the Islamic stance on homosexuality matters to them. In order to facilitative a positive self-concept among gay Muslims and harmonious relations between heterosexual and LGB Muslims, there will need to be a discernible change in social representations of homosexuality. This process will need to be supported by all sections of the Muslim community if it is to be successful.

\section{Cross-references}

Homosexuality and Christianity

Islam, Gender and Sexuality

LGBTTQ Activism, Middle East

LGBTTQ Activism, South Asia

Masculinities

Religion and Homophobia

Sexual Identity and Orientation

Sexual Identity Development

\section{References}

Amer, S. (2012). Naming to Empower: Lesbianism in the Arab Islamicate World Today. Journal of Lesbian Studies, 381-97. 
Bucar, E.M. \& Shirazi, F. (2012). The "Invention" of Lesbian Acts in Iran: Interpretative Moves, Hidden Assumptions, and Emerging Categories of Sexuality. Journal of Lesbian Studies, 16(4), 416-34.

Bouhdiba, A. (1998). Sexuality in Islam. London: Saqi Books.

Breakwell, G. M. (1986). Coping with threatened identities. London: Methuen.

Duran, K. (1993). Homosexuality in Islam. In A. Swidler (Ed.) Homosexuality and World Religions (pp.181-98). Harrisburg, Pennsylvania: Trinity Press International.

Kugle, S.S.A. (2010). Homosexuality in Islam: Critical Reflection on Gay, Lesbian, and Transgender Muslims. Oxford: Oneworld Publications.

Jaspal, R. (2012). Coping with cultural and religious homophobia: emotion and narratives of identity threat from British South Asian gay men. In A.K.T. Yip \& P. Nynas (eds.), Religion, Gender and Sexuality in Everyday Life (p. 71-90). Aldershot: Ashgate.

Jaspal, R. (2014a). Arranged marriage, identity and psychological wellbeing among British Asian Gay Men. Journal of GLBT Family Studies 10(5), 425-448.

Jaspal, R. (in press). The experience of relationship dissolution among British South Asian gay men: Identity threat and protection. Sexuality Research \& Social Policy.

Jaspal, R. \& Cinnirella, M. (2010). Coping with potentially incompatible identities: accounts of religious, ethnic and sexual identities from British Pakistani men who identify as Muslim and gay. British Journal of Social Psychology, 49(4), 849-870.

Jaspal, R. \& Cinnirella, M. (2014). Hyper-affiliation to the religious ingroup among British Pakistani Muslim gay men. Submitted to Journal of Community and Applied Social Psychology, 24(4), 265-277.

Mirza, M., Senthilkumaran, A. \& Jafar, Z. (2007). Living apart together: British Muslims and the paradox of multiculturalism. London: Policy Exchange.

Murray, S.O (1997). The will not to know: Islamic accommodations of male homosexuality. In S.O. Murray \& W. Roscoe (eds.), Islamic homosexualities: Culture, history and literature (pp.14-54). New York, NY: New York University Press.

Siraj, A. (2012). "I Don't Want to Taint the Name of Islam": The Influence of Religion on the Lives of Muslim Lesbians. Journal of Lesbian Studies, 16(4), 449-67.

Wafer, J. (1997). Mohammad and male homosexuality. In S.O. Murray \& W. Roscoe (eds.), Islamic Homosexualities: Culture, History and Literature (pp. 87-96). New York: New York University Press.

Yip, A.K.T. (2005) Queering religious texts: An exploration of British non-heterosexual Christians' and Muslims' strategy of constructing sexuality-affirming hermeneutics.

Sociology, 39(1). 47-65. 